\title{
Chagasic enteropathy
}

\author{
Enteropatia chagásica
}

\author{
Ulysses G. Meneghelli ${ }^{1}$
}

\begin{abstract}
Involvement of the hollow organs of the digestive apparatus can occur in patients in the chronic phase of Chagas' disease. The basic mechanism is destruction of neurons of the enteric nervous system. Whereas megaesophagus and megacolon are the most notable and most extensively studied expressions of the digestive form of Chagas' disease, involvement of the small intestine (Chagasic enteropathy) is less frequent and less known than involvement of the two above mentioned entities. Chagasic enteropathy can be responsible for important clinical and laboratory manifestations resembling those of dyspeptic syndrome, intestinal pseudo-obstruction and bacterial overgrowth in the small intestine. Chagasic enteropathy also involves peculiar functional changes, especially those related to motor activity of the organ and to intestinal absorption of carbohydrates. In practice, the diagnosis is based on radiographic documentation of dilation of visceral segments. Treatment consists of clinical control of the above syndromes and, eventually, appropriate surgical operations.
\end{abstract}

Key-words: Chagas' disease. Chagasic enteropathy. Physiopathology of the small intestine.

\section{RESUM0}

0 comprometimento dos órgãos ocos do aparelho digestivo pode ocorrer nos portadores da fase crônica da doença de Chagas. 0 mecanismo básico é a destruição dos neurônios do sistema nervoso entérico. Conquanto o megaesôfago e 0 megacólon sejam as expressões mais notáveis e estudadas da forma digestiva da doença de Chagas, o envolvimento do intestino delgado (enteropatia chagásica) é menos freqüente e menos conhecido do que o das duas entidades mencionadas. A enteropatia chagásica pode ser responsável por importantes manifestações clínicas e laboratoriais que se assemelham às das síndromes dispéptica, de pseudo- obstrução intestinal e de supercrescimento bacteriano no intestino delgado. A enteropatia chagásica também acarreta peculiares alterações funcionais, particularmente relacionadas à atividade motora do órgão, bem como, à absorção intestinal de carboidratos. Na prática, o diagnóstico fundamenta-se na documentação radiográfica da ectasia de segmentos da víscera. 0 tratamento comporta 0 controle clínico das síndromes acima mencionadas e, eventualmente, operações cirúrgicas apropriadas.

Palavras-chaves: Doença de Chagas. Enteropatia chagásica. Fisiopatologia do intestino delgado.

Chagas' disease is provoked by the protozoon Trypanosoma cruzi, Chagas, 1909. The acute form of the disease can be particularly severe or even lethal, but may also be non-apparent or may be confused with other acute infectious diseases. More frequently the disease is diagnosed during the chronic phase, many years after the acute phase, when the major and most common manifestations of the disease are due to cardiac involvement (arrhythmias, disorders of nerve impulse conduction, cardiomegaly, heart failure and sudden death) and/or digestive tract involvement (dysphagia, megaesophagus, intestinal constipation, megacolon). The predominance of one or another of these manifestations is the basis for the recognition of the $\operatorname{cardiac}^{10}$ and digestive ${ }^{56}$ forms of the disease, as opposed to the indeterminate form. The latter form is characterized by: 1. a positive specific serologic test or positive demonstration of the parasite; 2. absence of any symptom and/or sign of the disease; 3. normal conventional ECG; and 4. normal heart, esophagus and colon X-ray

1. Departamento de Clínica Médica da Faculdade de Medicina de Ribeirão Preto da Universidade de São Paulo, Ribeirão Preto, SP. Address to: Dr. Ulysses G. Meneghelli. Av. Sumaré 414, 14025-450 Ribeirão Preto, SP, Brazil

Fax: 5516 633-6695

e-mail: ugmenegh@fmrp.usp.br

Recebido para publicação em 25/3/2004

Aceito em 2/4/2004 
images ${ }^{28}$. However, it must be considered as a transitory form of the disease, since about 2-5\% of patients with this form progress to the symptomatic cardiac and/or digestive disease each year ${ }^{16} 58$.

The etiology of megaesophagus and megacolon, which are endemic in South America and especially in the rural zones of Brazil, was only linked to Chagas' disease more than 40 years after the discovery of the disease, based on serologic ${ }^{19}$ and histopathological ${ }^{25}$ studies, on experimental reproduction of the disease in laboratory animals $s^{4}$, and on patient follow-up after the acute phase of the disease ${ }^{54}$. Although megaesophagus and megacolon are the most common and most expressive digestive manifestations of the chronic phase of Chagas' disease, others occur less frequently, such as megaduodenum, megajejunum and megaileum. In addition, dysfunction of the small intestine of Chagasic patients can be demonstrated by functional tests even in the absence of symptomatic manifestations. The involvement of the small intestine by Chagas' disease may be called Chagasic enteropathy and it can occur in the dilated or non-dilated form.

The pathogenesis of dysfunction and dilation of segments of the digestive tract in Chagas' disease is based on denervation of the complex network of intramural neurons, today known as enteric nervous system, that controls many of the functions of the digestive tract ${ }^{20}$. The destruction of intramural neurons in megaesophagus and megacolon was identified many years $\mathrm{ag} 0^{517}$ and was later confirmed by meticulous neuronal counts performed in megaesophagus and in non-dilated esophagus, in the stomach , in different parts of the small intestine, in megacolon, and in nondilated colon of Chagasic patient ${ }^{24}$. Recently, new counts were done considering the neuronal hypertrophy that occurs in Chagasic megacolon and the authors found that denervation was greater than $55 \%$ in $76.5 \%$ of cases $^{1}$, confirming early studies by Koeberle ${ }^{24}$.

The mechanisms determining the degenerative lesions of the neurons and even their complete destruction in the viscera of the digestive tract of Chagasic patients are still incompletely understood. They act starting from the acute phase of the disease $\mathrm{e}^{23}$ but continue during the chronic phase. It was first proposed that a neurotoxin released by the parasite near the focal points of infection during the acute phase of the disease was a preponderant determinant of neural injury ${ }^{23}$. The possibility that the inflammatory process itself may be the cause of denervation or that denervation may result from the participation of specific cellular and humoral responses to T. cruzi developed by the host, including autoimmunity, has been raised since then ${ }^{69} 606264$. However, until now there is no definitive proof that autoimmunity is the primary cause of the events occurring in chronic Chagas' disease and one area of agreement that has emerged in recent years is that parasite persistence is required for diseas $e^{62}$. In situ PCR analysis performed in murine models of Chagas' disease has demonstrate a correlation between the persistence of parasites and the presence of disease in muscle tissue ${ }^{71}$. The observation that T. cruzi infection can be reactivated in patients with therapeutic or pathological immunosuppression also favors the point of view that chronic Chagas' disease is a parasiteinduced disorder ${ }^{64}$.
In this presentation, Chagasic enteropathy will be approached from the viewpoint of involvement of the duodenum, jejunum and ileum alone or in combination, due to Chagas' disease in the chronic phase. Chagasic enteropathy is much less frequent and less studied than esophageal and colon disease of the same etiology. However, studies on this type of disease are important to expand knowledge about the digestive form of Chagas' disease, to include it among the causes of the intestinal pseudo-obstruction syndrome and of bacterial overgrowth in the small intestine, and mainly for adequate diagnosis and treatment.

\section{STRUCTURAL CHANGES}

Small bowel dysfunction and dilation are mainly due to the lesions and destruction of neurons of the enteric nervous system in the involved viscera. In experimentally infected animals, denervation of the submucosal and myenteric plexuses of the small bowel has been confirmed ${ }^{34}{ }^{42}$. The same occurs in naturally infected cats and dogs ${ }^{26}$. The percentages of denervation shown in Table 1 were detected in humans with the chronic phase of Chagas' disease and with no dilation of any segment of the small bowel. In cases of enteric megas, denervation is likely to reach much higher percentages, as also observed in megaesophagus and megacolon. The complete disappearance of intramural neurons has been documented in cases of megaduodenum ${ }^{52}$.

Table 1 - Percent reduction in the number of neurons of the enteric nervous system of the small bowel of patients with chronic Chagas' disease.

\begin{tabular}{lcc} 
& Submucosal plexus (\%) & Myenteric plexus (\%) \\
\hline Duodenum $^{13}$ & 50 & 50 \\
Jejunum $^{4}$ & 33 & 36 \\
Ileum $^{14}$ & 42 & 51 \\
\hline
\end{tabular}

As a consequence of denervation, the duodenum becomes hypersensitive to cholinergic agents. Intraluminal application of acetylcholine in the proximal small intestine provokes more intense and more prolonged motor activity than in normal individuals ${ }^{36}$. This type of response to acetylcholine or to one of its analogues can be a way to demonstrate intramural denervation. The Mecholyl (metacholine) test performed with manometric monitoring of the duodenum showed hyperactive reactions in $70 \%$ of Chagasic patients with megaesophagus, as opposed to only $10 \%$ of Chagasic patients withoutmegas, demonstrating that duodenopathy is more frequent in patients with clear involvement of other segments of the digestive tube by the disease $\mathrm{e}^{57}$.

Electron microscopy reveled that the neuronal lesions of the jejunum are less intense than those of the megaesophagus or megacolon and that the remaining cells show ultrastructural lesions ${ }^{61}$. The least damaged cells show an increase in the number and volume of osmophilic granules suggesting hypersecretion of neurotransmitters, perhaps reflecting the complexity of the disorder of neuroregulation of the functions of the organ. The presence of inflammatory foci and of 
interstitial fibrosis in smooth muscle has also been recorded ${ }^{61}$. Hypertrophy of the circular and longitudinal musculature has been detected in the duodenum ${ }^{52}$.

The final result of denervation of the enteric nervous system determined by Chagas' disease is dilation of the involved organ, the most expressive manifestation of the digestive form of the disease. Koeberle ${ }^{23}$ proposed that, as a consequence of damage to intramural innervation, motor uncoordination of the involved visceral organ occurs, followed by delayed transit of its content, stagnation and retention, continuous distention of muscle fibers which become hypertrophied, and finally dilation mega. He considered the functional status of the visceral organ to be an important factor in the determination of the mega. According to the cited author, the mega will develop only if the functional activity of the visceral organ is continuously required. He proposed that dilation of the esophagus and colon occurs more frequently than dilation of other viscera of the digestive tube because more demands are made on these organs since, in contrast to other segments and especially the small bowel, they work with solid material. He considered the presence of a defect in sphincter function to be an important factor in the development of the mega, as is the case for megaesophagus, but not an essential one, citing the megaduodenum and megajejunum as proof. He also stated that the degree of denervation and of the corresponding functional disorder may affect the duration of the time needed for the development of the mega. However, other factors have been considered to participate in the pathogenesis of the megas ${ }^{60}$. The detection of megas in the small bowel is not frequent, but the megaduodenum is considered to be the segment of the digestive tube that is most often found to be dilated after the colon and esophagus; in most cases the dilation is restricted to the duodenal cap. In a series of 800 autopsies, 185 cases of megacolon, 158 of megaesophagus and only 20 of megaduodenum and 4 of megajejunum were detected ${ }^{24}$. Dilation of the ileum is extremely rare $^{59}$. Dilation of the segments of the small bowel is frequently associated with megaesophagus and/or megacolon ${ }^{52}{ }^{57}$. When a radiological method is used, however, the incidence of megaduodenum increases. Fonseca ${ }^{18}$ detected dilation of the first portion of the duodenum in $30 \%$ of cases of megaesophagus.

\section{PATHOPHYSIOLOGY}

Motility. The function most consistently found to be altered in Chagasic enteropathy is motor activity, which greatly depends on the regulatory activity of the enteric nervous system. Although dilation of the duodenum, jejunum and ileum is not frequent, the motor impairment of segments of the small bowel is high in the digestive form of Chagas' disease. Radiological studies performed many years ago revealed a high incidence of changes in tonus and transit time in the duodenum, jejunum and ileum of patients with megaesophagus ${ }^{1865}$. Manometry of the proximal small bowel of Chagasic patients has also revealed frequent motility abnormalities both under fasting and postprandial conditions, especially in those with megaesophagus and/or megacolon ${ }^{35456}$. This fact agrees with the high prevalence of a positive denervation test (Mecholyl) found in the small bowel of patients with Chagasic megaesophagus ${ }^{57}$.

Normally, during fasting the small intestine presents successive cycles of motor activity known as migrant motor complex (MMC). At intervals of 80 to 120 minutes a set of repeated contractions of frequency identical to the basic electric rhythm (BER) (12/min) occurs in the duodenum. These contractions cover a segment of about $25 \mathrm{~cm}$ and migrate in a caudal direction, and their frequency is progressively reduced, reaching $7-8 / \mathrm{min}$ in the ileum. The velocity of migration of the set of contractions is about 6 to $8 \mathrm{~cm} / \mathrm{min}$ in the duodenum-proximal jejunum. The duration of the sequence of contractions at the recording point is about $5 \mathrm{~min}$ in the proximal jejunum. This type of motor activity is phase 3 of the MMC and is followed by phase 1, characterized by motor quiescence and refractoriness, which lasts 15 to 60 minutes. The motor activity then reappears gradually in the form of distinctperiod of intermittentand apparently irregular phasic contractions ( phase 2) until it culminates in a new phase 3 . The motor activity of the interdigestive period has been proposed to be important to lead to the colon non-absorbed food remains, secretions and cell detritus which, if retained, would favor excessive bacterial proliferation. The pattern of contractions that characterizes the MMC is immediately interrupted by food ingestion, with the occurrence of a motor activity comparable to phase 2 of the MMC and called postprandial or fed pattern. The duration of MMC interruption by a meal depends on the composition and the physical properties of the food ingested ${ }^{12}$; fed pattern duration of about 180, 360 and 410 minutes occur in healthy individuals after meals of 630, 1,260 and 2,500kJ, respectively $\mathrm{y}^{22}$.

Aclear manometric abnormality detected in the proximal small bowel of fasting Chagasic patients is the reduction in the velocity of propagation of phase 3 (Figure 1). The calculated length of the intestinal segment in phase 3 was lower than normal and duration of phase 3 was also shown to be longer in the jejunum but not in the duodenum, in comparison to normal. These alterations mainly occurred among patients with megaesophagus and/or megacolon.

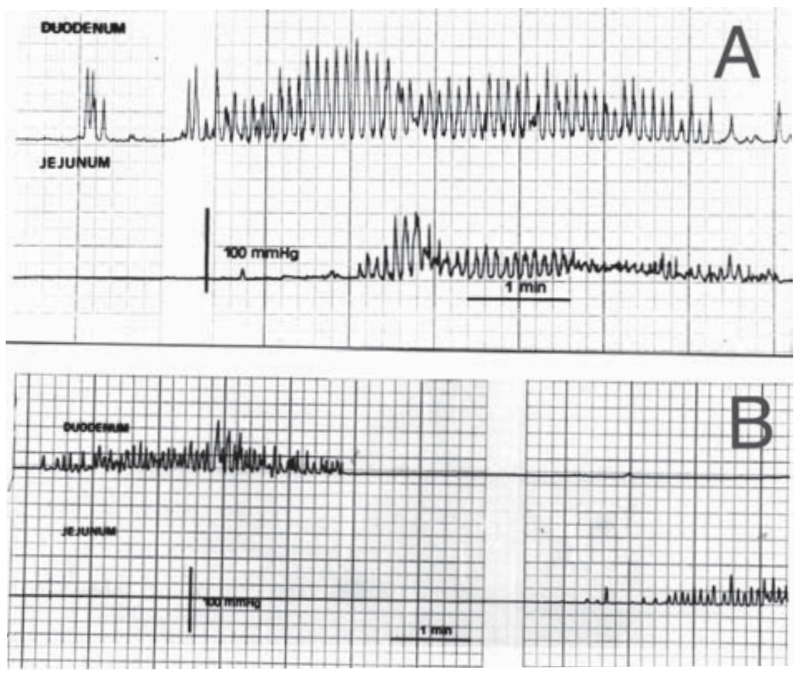

Figure 1 - Recordings of fasting small intestine motility in a control subject (A) and in a patient with Chagasic enteropathy (B). The migration of phase 3 from the duodenum to the proximal jejunum (30 cm apart) is slower in the Chagasic patient. 
These alterations of the phase 3 of the MMC observed in the manometric recordings of fasting motility of the small intestine of Chagasic patients are detailed in Table $2^{46}$.

Table 2 - Some characteristics of phase 3 of the MMC observed by small intestine manometry of fasting patients with Chagas' disease with and without digestive pathology ${ }^{46}$.

\begin{tabular}{lclc}
\hline Phase 3 of MMC & Controls subjects & \multicolumn{2}{c}{ Chagas' disease patients } \\
\hline Velocity of propagation & $9.4(6.1-24.0)$ & all & $4.7(1.6-18.0)^{*}$ \\
$(\mathrm{~cm} / \mathrm{min})$ & & wit mega & $4.5(1.6-15.0){ }^{* *}$ \\
& & no mega & $7.9(6.0-18.0)$ \\
Calculated length $(\mathrm{cm})$ & $42.4(29.6-78.4)$ & all & $29.8(11.7-89.2) * * *$ \\
& & with mega & $27.8(11.7-89.2)^{* * *}$ \\
& & no mega & $47.5(26.6-54.8)$
\end{tabular}

Duration ( $\min )$

$\begin{array}{llll}\text { Duodenum } & 4.6(1.8-7.0) & \text { all } & 5.6(3.8-12.3) \\ \text { Jejunum } & 4.4(3.1-5.6) & \text { all } & 6.5(3.0-22.3)^{* * * * *}\end{array}$

$* \mathrm{P}<0.001$ compared with controls. ${ }^{* *} \mathrm{P}<0.02$ compared with patients without mega and $\mathrm{P}>0.002$ compared with controls. ${ }^{* * *} \mathrm{P}<0.03$ compared with controls.

$* * * * \mathrm{P}<0.05$ compared with patients withoutmega and $\mathrm{P}>0.02$ compared with controls. $* * * * * \mathrm{P}<0.004$ compared with controls.

The frequency of contraction during the activity fronts is normal in Chagas' disease ${ }^{46}$. Considering that when an activityfront reaches a segment of the small bowel its mechanical contraction has the same rate as the basic electric rhythm (BER) of the segment ${ }^{11}$, it maybe concluded that the small intestinal BER is essentiallynormal in Chagas' disease even in patients with the above mentioned fasting motor abnormalities of this organ.

Another remarkable change observed in the motor activity of the small intestine of Chagasic patients is the non-interruption of the MMC by the ingestion of a meal of approximately $530 \mathrm{kcal}$ (Figures 2 and 3), which exclusively occurs in patients with megaduodenum and/or megajejunum ${ }^{35}$, or an attenuation of the responses to the meal revealed by prolonged manometry of the small bowel ${ }^{45}$.
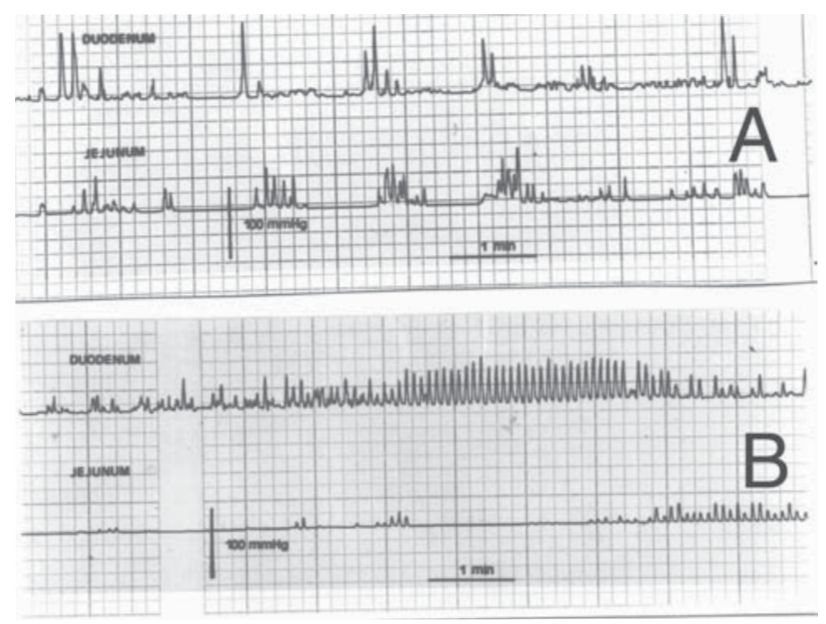

Figure 2 - Recordings of duodenal and jejunum motility around 30 minutes after the end of ingestion of a 530kcal meal. Distance between the points of recordings: $30 \mathrm{~cm}$. While the control patient (A) shows a characteristic fed pattern, the patient with Chagasic enteropathy (B) shows a typical phase 3 of the fasting state, indicating that feeding does not disrupt the small intestine interdigestive motor pattern.
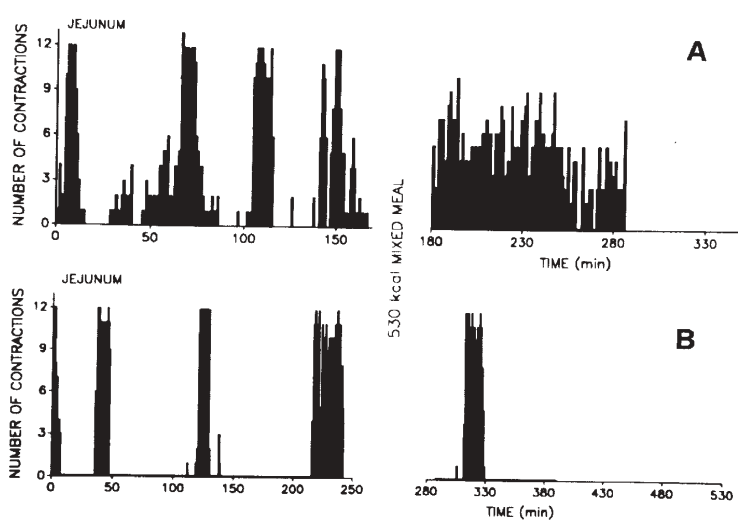

Figure 3 - Condensed presentation of manometric tracings for the jejunum of a normal person (A) and of a patient with Chagasic megajejunum (B) over a period of approximately 330 minutes during which a meal was consumed. The tracing for the normal jejunum shows that before the meal there were four periods during which motor activity reached a frequency of 12 waves /min (the same as for BER) which correspond to phase 3 of MMC. Among the 3 phases, phase 1 is identified by quiescence and phase 2 by activity of medium intensity. After the meal, the interdigestive pattern is replaced by intense activity devoid of the cyclic configuration of the interdigestive period. The tracing obtained for the patient with megajejunum shows that ingestion of the meal did not interrupt the MMC, since a short period of quiescence after the meal was followed by a set of contractions occurring at a frequency of 12 waves/min, typical of phase 3 of $\mathrm{MMC}^{49}$.

Considering that Chagas' disease may be seen as a natural human model of denervated digestive viscera ${ }^{33}$, these manometric findings permit a suggestion of a physiological nature: the integrity of the enteric nervous system in the small intestine is necessary for the normal migration of the MMC as well as for its interruption by food ingestion.

Gastric emptying of liquids is disturbed in Chagasic patients with a clear compromise of the duodenum. Gastric emptying of an isotonic dextrose solution studied by the scintigraphic method showed that the early phase of emptying in a group of patients with megaduodenum is abnormally accelerated in comparison with patients with Chagas' disease but without megaduodenum and with healthy volunteers. An increased duodenal receptivity is supposed to be the cause of this abnormality ${ }^{68}$.

Transit time studies using scintigraphy methods and a conventional $\mathrm{H}_{2}$ breath technique were performed in Chagasic patients with at least one manifestation of the digestive form of the disease, but with no significant retention of liquids in the esophagus. These studies showed a delayed arrival of the test meal to the cecum associated with slow transit in the distal small bowel ${ }^{69}$.

The changes in small bowel motility caused by intramural denervation maycreate conditions that favor bacterial proliferation due to content stagnation. In fact, hyperproliferation of aerobic bacteria and the presence of anaerobic bacteria in the small bowel have been documented in patients with Chagasic megaesophagus and/or megacolon, with the number of colonies being as high in some cases as those occurring in patients with the clinical syndrome of bacterial overgrowth in the small bowel ${ }^{29}{ }^{31}$. Since the 
participation of changes in gastric secretion was excluded, the abnormality was attributed to disorders of local motility ${ }^{30}$. In support of this hypothesis, it was observed that two cases of Chagasic megajejunum with clearly detectable alterations upon manometry and with confirmed bacterial overgrowth in the small bowel developed the typical clinical syndrome of bacterial overgrowth (chronic diarrhea, evidence of malabsorption and improvement with antibacterial treatment) ${ }^{9}$. The accumulation of fecal material in the dilated colon can facilitate bacterial proliferation in the small bowel, as suggested by the observation that surgical removal of the megacolon causes a decrease in the proximal jejunum microflora in $83 \%$ of the patients ${ }^{51}$.

Absorption. This function has not been extensively studied in Chagas' disease. It was first observed that Chagasic patients, especially those with clear involvement of the digestive tube as revealed by megaesophagus or megacolon, presented abnormal responses to the oral glucose tolerance test (GTT) ${ }^{55}$, and to the galactose ${ }^{39}$ and xylose ${ }^{41}$ overload test. The abnormal response to an oral overload with these monosaccharides was characterized by a high peak of their concentration in blood 30 minutes after ingestion, followed by a rapid fall. Abnormal GTT curves were detected in about $65 \%$ of patients with digestive tube megas ${ }^{32}$. On the other hand, the responses to an intravenous glucose overload did notdiffer between Chagasic patients and controls ${ }^{40}$. These facts suggest that rapid monosaccharide absorption may occur in Chagas' disease, explaining the abnormalities observed when an overload of these substances was administered orally. Another possibility could be that the rapid gastric emptying of the test solution immediatelyafter ingestion may expose the proximal small bowel to an excessive amount of monosaccharide, forcing rapid absorption. Favoring this hypothesis, it was demonstrated that an accelerated emptying of the liquid contained in the gastric cavity occurs probably due to the loss of the ability of the Chagasic stomach to accommodate to distention ${ }^{48}$.

In order to test directly the absorption ability of the proximal small bowel of Chagasic patients, the method of continuous intestinal perfusion with an indicator of variation in dilution was used. Glucose solutions of four different increasing concentrations $(0.5,1.0,2.5$, and $5 \%)$ were infused at a constant flow through a tube placed in the distal duodenum or proximal jejunum over a standardized period of time, and samples were collected $30 \mathrm{~cm}$ downstream from the point ofinfusion. One percentpolyethylene glycol ( PEG 4000) was added to the infused glucose solution. PEG determination in each distal sample was necessary to correct the variation of glucose concentration due to glucose dilution occurring along the chosen intestinal segment. This method permitted an estimate of the amount of glucose absorbed between the point of infusion and the point of aspiration. Considering that glucose absorption is a function of its concentration in the solution in contact with the mucosa until reaching a saturation point (Michaelis-Menten kynetics ${ }^{21}$, the data obtained were used to study the kinetics of glucose absorption and to constructa dose-response type of curve. The intestinal segment under study in Chagasic patients with an abnormal GTT was found to show kinetic characteristics indicating a greater capacity for glucose transport ( greater Vmax), but less affinity ( greater $\mathrm{Km}$ ) than controls (Figure 4) ${ }^{36}{ }^{37}$. The curves in Figure 4 were drawn by plotting the corresponding values of perfused glucose ( $\mathrm{g} / \mathrm{min}$ ) and absorption velocity $(\mathrm{g} / 30 \mathrm{~cm} / \mathrm{min})$ calculated from the regression line equations. These curves demonstrate that for a given amount of glucose in the intestine,

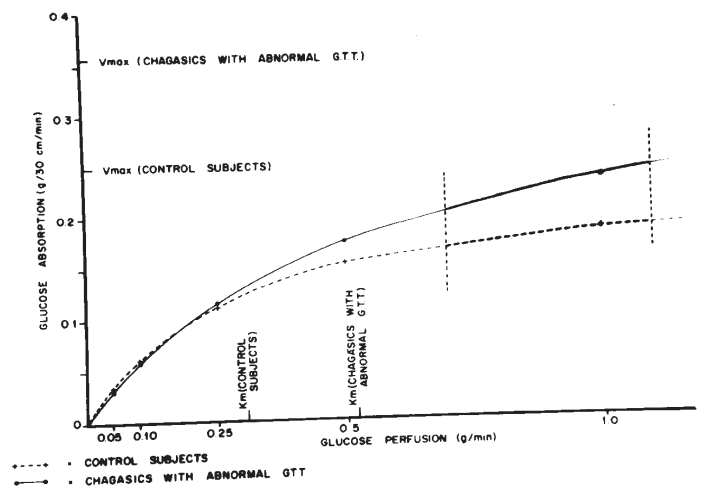

Figure 4 - Relation between glucose absorption rates and glucose concentrations in the perfused solution in the small bowel. These curves were calculated from the regression line equations. The vertical dotted lines mark the limits of the glucose concentration encountered in the duodenum during the initial phases of the GTT ${ }^{3637}$.

when the glucose administered is above $0.25 \mathrm{~g} / \mathrm{min}$, the transfer of sugar to the blood is greater in Chagasics than in controls. During the first 30 minutes of the GTT the fluid collected through a duodenal probe has a glucose concentration from 7 to $11 \mathrm{~g} / 100 \mathrm{ml}$. In Figure 4 these values were situated between the two vertical dotted lines which enclose a region where the curves show a clear difference in absorption rate between Chagasics and control individuals. Thus, an epithelium with a greater absorption capacity permitting monosaccharide hyperabsorption may explain, at least in part, the abnormal GTT of Chagasic patients. It has been proposed that this dysfunction in glucose absorption may be determined by the intramural denervation of the small bowel demonstrated in Chagas' disease ${ }^{3238}$. Also we may assume that the accelerated gastric emptying of a glucose solution observed in Chagasic patients ${ }^{48}$ may have an adaptive action in their intestinal absorptive epithelium inducing a high capacity to absorb in order to avoid the undesirable effect of a high osmolarity in the lumen of the small intestine by a local high carbohydrate concentration.

The ${ }^{131}$ I oleic acid test used at the time to study lipid absorption showed low radioactivity curves in blood after ingestion in $30 \%$ of the Chagasic patients studied. Considering that most of these patients showed normal gastric emptying as evaluated by a radiological method, it was concluded that the disease may cause a slow lipid absorption but without affecting the total amount absorbed since fecal radioactivity was normal ${ }^{37}$. Intestinal absorption was later studied in Chagasic patients by the intrajejunal administration of ${ }^{131}$ I oleic acid. Since no differences in results were observed between Chagasic patients and controls, it was concluded that the abnormalities observed in the oral test were probably due to delayed gastric emptying of the test meal ingested ${ }^{47}$.

Secretion. The mucosa of the small bowel contains cells whose function is to secrete peptides having the most varied 
regulatory actions both locally and at a distance. Intramural denervation would be expected to have some effect on this secretion. However, it was observed that Chagasic patients with clear impairment of the digestive tract shown by megaesophagus did not present any abnormality in motilin, enteroglucagon or gastric inhibitor peptide levels either under basal conditions or after stimulation by an oral or intravenous glucose overload or by insulin hypoglycemia ${ }^{27}$. In another study on this same type of patients, no changes in cholecystokinin, motilin or enteroglucagon levels were detected in the basal state or after intravenous administration of secretin associated or not with duodenal instillation of phenylalanine $e^{43}$.

Immune function. It is known that one of the targets of the enteric nervous system are the immunomodulatory and inflammatory cells of the gut ${ }^{20}$. However, there are only a few publications about the relationship between the involvement of the digestive tube by Chagas' disease and the immune system of the intestine. Specific IgA antibody classes were detected predominantly in patients with the digestive form of the disease (92\%) in contrast with $20 \%$ of patients with the cardiac form and $21.4 \%$ of patients with the indeterminate form ${ }^{50}$. Elevation of serum IgA levels in Chagas' disease was observed only in patients with concomitant dilation of the esophagus and colon while Chagasic patients with the cardiac or indeterminate forms of the disease did not show this abnormality? Considering that the small bowel has the greater concentration of IgA-producing cells in the entire digestive tract, it was supposed that the Chagasic patients with megaesophagus and megacolon could also have an involvement of the small intestine which would be the responsible for the higher serum IgA levels observed ${ }^{7}$. Patients with Chagasic enteropathy, defined by organ dilatation or motor abnormality, presented higher serum IgA levels than patients without enteropathy ${ }^{8}$. Secretory IgA in the intestinal aspirate showed concentrations above the levels described for normal control individuals referred to in literature; however, there were no differences when the results of patients with Chagasic enteropathy were compared to those of patients who did not present enteropathy8.

\section{CLINICAL MANIFESTATIONS AND DIAGNOSIS}

The clinical manifestations of Chagasic enteropathy occur after the development of dilatation of one or more of the anatomical segments of the small bowel, They are almost always associated with concomitant symptoms of megaesophagus and/or megacolon. The presence of only motor or absorptive dysfunction of the small bowel, detectable by special tests, does not seem to be sufficient to provoke symptoms or signs of significance to the patient. There is no systematic description of the manifestations of Chagasic small bowel megas. Investigators of the digestive form of Chagas' disease have reported only few personally observed cases ${ }^{535767}$. Particularly outstanding in this respect is the report by Raia et $a 1^{52}$ of 11 cases of megaduodenum.
There is a wide gamut of clinical expressions of ectatic Chagasic enteropathy, ranging from the absence of symptoms, with detection only by radiological examination indicated for other purposes, to signs and symptoms belonging to at least three types of syndromes: dyspeptic syndrome, intestinal pseudo-obstruction syndrome, and bacterial overgrowth syndrome of the small bowel. It may be stated that clinical manifestations tend to be more expressive and severe the greater the extent of dilation of the small bowel.

Within the dyspeptic picture, patients with megas of the small bowel may present a sensation of postprandial fullness and discomfort in the epigastrium ${ }^{5767}$. Pain, which is notalways present, may vary in intensity and type and may occur during the early or late postprandial period. Raia etal ${ }^{5253}$ pointed out that the clinical picture of megaduodenum can be that of gastric stasis of a progressive nature, characterized byvomiting of food ingested many hours before, dehydration, epigastric pain and visible gastric peristalsis, and lesions of the duodenal and gastric mucosa, and includes the possibility of bleeding and even stomach rupture. Another important complication is represented by esophageal mucosa injuries due to prolonged contact with material stagnating in the stomach, with reflux into the esophagus. In a case observed by us, reflux disease was present in a particularly severe form since it was facilitated by a previous surgical intervention in the cardia for the treatment of megaesophagus. It should be remembered that gastric stasis in the absence of small bowel dilation in Chagasic patients maybe due to gastropathy of the same etiology ${ }^{5370}$. As previously mentioned, cases of megajejunum are rare. In the few cases we observed, the condition was always associated with megaduodenum. Megajejunum has also been reported to occur separately or associated with megaileum ${ }^{53767}$.

Patients with megajejunum may be asymptomatic or may present well defined clinical signs and symptoms such as intestinal pseudo-obstruction associated or not with syndrome of bacterial overgrowth in the small bowel. Abdominal distention, the presence of continuous pain or of cramps, the visible peristalsis, the intestinal constipation and the detection of fluid levels in small bowel loops by simple abdominal radiography in the orthostatic position are the elements composing the picture of pseudo-obstruction of the small bowel.

The occurrence of continuous chronic diarrhea or of diarrhea alternating with periods of intestinal constipation or other symptoms of pseudo-obstruction suggests a diagnosis of bacterial overgrowth in the small bowel. This hypothesis is reinforced when there is evidence of intestinal malabsorption such as weightloss and clinical and laboratory signs of steatorrhea, anemia or hypocalcemia. The diagnosis of bacterial overgrowth may be confirmed by the demonstration of strictly anaerobic bacteria in the upper portions of the small bowel, where they are not normally found, or by the increased number of colonies in duodenal aspirates ${ }^{96} 67$. The hydrogen breath testmayalso indicate the presence of bacterial overgrowth ${ }^{9} 2516667$. The presence of a high hydrogen rate in expired air when the patient is still fasting also indicates the syndrome of bacterial overgrowth of the small bowel ${ }^{9}$. Complete remission of diarrhea and general clinical 
improvement of the patient with antibiotic treatment may be considered to be a positive diagnostic test for the syndrome ${ }^{9}$.

The patient with megaileum described by Santos eta ${ }^{59}$ presented chronic diarrhea, abdominal distention and signs and symptoms of intestinal subocclusion resolved by clinical treatment. In summary, clinical manifestations similar to those of megajejunum.

The diagnosis of dilation of small bowel segments due to Chagas' disease is confirmed by standard radiological examination of the duodenum or the entire small bowel. This examination permits the identification of the duodenal cap or of other segmental dilations of the duodenum, the megajejunum, megaileum, and total dilation of the small bowel ( Figure 5). These examinations are also useful for the obligatory differential diagnosis with organic causes of intestinal obstruction.

Endoscopic examination is indicated for the diagnosis of changes in the mucosa of the esophagus, stomach and duodenum consequent to stasis, which may range from inflammation to ulcer and bleeding, and may also aid the differential diagnosis with organic causes of stomach and duodenum obstruction. It may also indicate the diagnosis of megaduodenum.
For an etiological diagnosis it is indispensable to confirm serologicallythe presence ofChagas' disease byimmunofluorescence or by any other test with good performance.

The differential diagnosis of dilated Chagasic enteropathy can be made with a wide variety of uncommon diseases ${ }^{31}{ }^{34}$. However, the concomitant megaesophagus and megacolon and/or Chagas heart disease, epidemiological data and a positive serologic test clearly point to the diagnosis.

\section{TREATMENT}

When the patient only presents dyspeptic symptoms, treatment may be limited to dietary adjustments, especially with the recommendation of bland meals free of substances that irritate the mucosa, reduction of the amounts of fatty foods, meals of small volume, and good food mastication. Although the efficacy of prokinetic medications in these pathological conditions is unknown, the use of domperidone at habitual doses could be attempted. In the presence of reflux
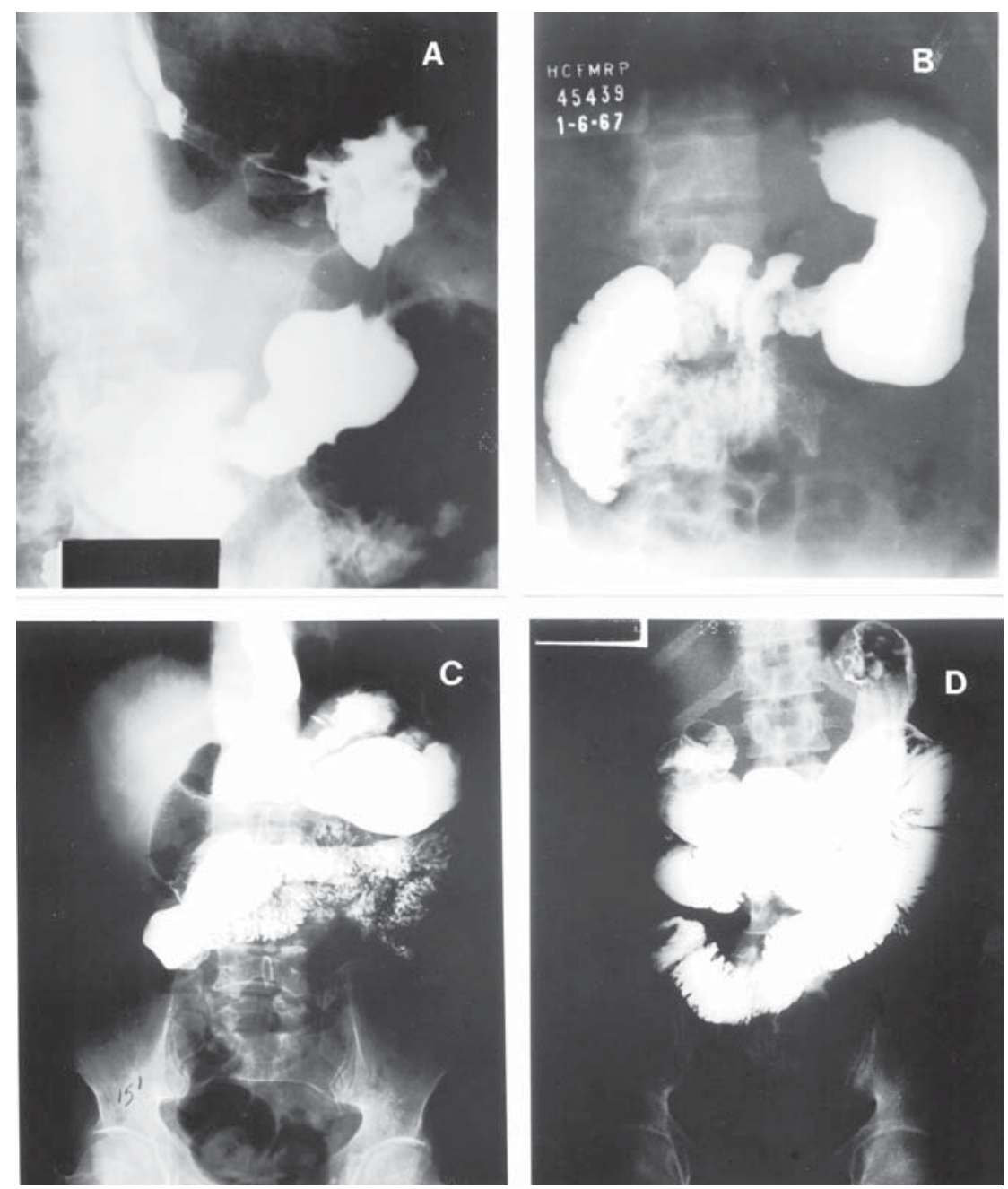

Figure 5 - Contrast radiographs of the proximal small bowel of four patients with Chagasic dilated enteropathy. A - dilated duodenal cap; B - megaduodenum; C - dilated duodenal cap and dilation of the second portion of the duodenum (filled with air) in a patient with a duodenum-jejunum surgical anastomosis for a megaduodenum; D - megaduodenum and megajejunum. 
esophagitis, proton pump inhibitors are indicated even for continuous use, the same applying to the presence of marked gastritis or duodenitis.

Surgical treatment of megaduodenum is reserved for cases in which stasis is clinically important and consists of duodenojejunal anastomosis close to the duodenojejunal angle, this being the type of operation mostfrequentlyperformed by Raia etal ${ }^{5253}$. Rezende ${ }^{57}$ pointed out that surgical treatment should be indicated only in cases in which the symptoms are unequivocally due to the megaduodenum and not only on the basis of radiological findings. In cases of megajejunum or megaileum, partial enterectomy may be indicated if the respective dilated segments are not extensive ${ }^{57}$. The operations, however, should be avoided when long segments of the small bowel are dilated. In these cases, clinical treatment of the obstructive episodes should be instituted, with interruption of oral feeding, continuous gastric aspiration, correction of dehydration and of electrolyte disorders and, eventually, the use of total parenteral nutrition ${ }^{5767}$.

Bacterial overgrowth syndrome of the small bowel should be treated with antimicrobial drugs (tetracycline, chloramphenicol, cephalosporin, metronidazole, etc), usually at similar or even lower doses than those used for the treatment of infectious processes, for 3 or 4 weeks. Bacterial sensitivity tests do not always indicate the best antibiotic for each case. Since the motor abnormality is persistent, the periodic use of antimicrobial agents may be necessary. If the picture is not resolved with a given antibiotic, indicating bacterial resistance, it is necessary to switch to another one. Associated nutritional disorders due to the malabsorption provoked by bacterial overgrowth should also be corrected.

Considering that parasite persistence is required for disease evolution in the chronic phase, it is supposed that a reduction of parasitic burden produced by chemotherapy or any other procedure could enhance anti-T. cruzi immunity and will be beneficial to the patient ${ }^{62}$. This hypothesis leads to the suggestion that an efficient preventive measure against more severe manifestations of the disease, such as cardiac manifestations and dilation of the organs of the digestive tube, could be achieved by chemotherapy if indicated in the recent chronic phase (infection acquired in the last 10 years), mainly in patients with the indeterminate form of the disease. However more efficient and less toxic drugs are required ${ }^{15}$.

\section{REFERENCES}

1. Adad SJ, Cançado CG, Etchebehere RM, Teixeira VP, Gomes UA, Chapadeiro E, Lopes ER. Neuron count reevaluation in the myenteric plexus of chagasic megacolon atter morphometric neuron analysis. Virchows Archives 438: 254258, 2001.

2. Alcântara FG, Costa RB. Jejunopatia chagásica. Revista Brasileira de Medicina 23: 316-317, 1966.

3. Alcântara FG, Oliveira JAM. Destruição neuronal no plexo de Auerbach em ratos chagásicos crônicos. Revista do Instituto de Medicina Tropical de São Paulo 6: 207-210, 1964.

4. Alcântara FG, Oliveira JAM. Fase crônica da moléstia de Chagas no rato Wistar. Pesquisas quantitativas dos neurônios no plexo de Meissner. Revista do Instituto de Medicina Tropical de São Paulo 6: 204-206, 1964.
5. Amorim M, Correa Netto A. Histopatologia e patogenese do megaesofago e megarreto (Considerações em torno de um caso de "Mal de engasgo"). Annaes da Faculdade de Medicina de São Paulo 8: 101-127, 1932.

6. Andrade SG, Andrade ZA. Doença de Chagas e alterações neuronais no plexo de Auerbach. Revista do Instituto de Medicina Tropical de São Paulo 8: 219-214, 1966 .

7. Andrade-Sá NM. Determinação dos níveis séricos de imunoglobulina da classe IgA em pacientes com as diferentes formas clínicas da fase crônica da doença de Chagas. Revista de Patologia Tropical 27: 107-152, 1998.

8. Andrade-Sá NM. IgA sérica e IgA secretória intestinal na enteropatia chagásica. Tese de doutorado. Universidade de São Paulo, Faculdade de Medicina de Ribeirão Preto, Ribeirão Preto, 2003.

9. Aprile LRO, Meneghelli UG. Síndrome do supercrescimento bacteriano no intestino delgado no megajejunum chagásico. Arquivos de Gastroenterologia de São Paulo 32: 71-78, 1995.

10. Chagas C. Nova entidade morbida do homem. Resumo geral de estudos etiolojicos e clinicos. Memórias do Instituto Oswaldo Cruz 3: 219-275, 1911.

11. Christensen J, Schedl HP, Clifton JA. The small intestine basic electrical rhythm (BER) in man. Gastroenterology 46: 773-774, 1964.

12. Cohen S, Snape Jr WJ. Movement of the small and large intestine. In: Sleisenger MH, Fordtran JS ( eds) Gastrointestinal Diseases, $4^{\text {th }}$ edition, WB Saunders Co. Fourth edition, Philadelphia (USA), p. 1088-1105, 1989.

13. Costa RB, Alcântara FG. Duodenopatia chagásica. Revista Brasileira de Medicina 23: 158-160, 1966.

14. Costa RB, Alcântara FG. Plexos submucoso e mioentérico do íleo humano na moléstia de Chagas. Revista Brasileira de Medicina 23: 399-400, 1966.

15. Coura JR, Castro SL. A critical review on Chagas disease chemotherapy. Memórias do Instituto Oswaldo Cruz 97: 3-24, 2002.

16. Dias JCP. The indeterminate form of human chronic Chagas' disease: a clinical epidemiological review. Revista da Sociedade Brasileira de Medicina Tropical 22: 147-156. 1989.

17. Etzel E. Neuropatologia do megaesofago e megacolo. Annaes da Faculdade de Medicina de São Paulo 10: 383-395, 1934.

18. Fonseca LC. Semiologia radiológica da discinesia funcional do duodeno. Arquivos de Cirurgia Clínica e Experimental 15: 176-200, 1952.

19. Freitas JLP. Contribuição para 0 estudo do diagnóstico da moléstia de Chagas por processos de laboratório. Tese de doutorado. Universidade de São Paulo, São Paulo, SP, 1947.

20. Goyal RK, Hirano I. The enteric nervous system. New England Journal of Medicine 334; 1106-1115, 1996

21. Holdsworth CD, Dawson AM. The absorption of monosaccharides in man. Clinical Sciences 27: 371-379, 1964.

22. Kellow JE. Manometry. In: MM Schuster, MD Crowell, Koch KL (eds) Schuster Atlas of Gastrointestinal Motility in Health and Disease, $2^{\text {nd }}$ edition, BC Decker Inc, Hamilton, Canada, pp. 219-36, 2002.

23. Koeberle F. Enteromegaly and cardiomegaly in Chagas disease. Gut 4: 399405, 1963.

24. Koeberle F. Chagas' disease and Chagas' syndrome; the pathology of American trypanosomiasis. Advances in Parasitology 6: 63-116, 1968.

25. Koeberle F, Nador E. Etiologia e patogenia do megaesophago no Brasil. Revista Paulista de Medicina 47: 643-661, 1955.

26. Koeberle GAF. 0 plexo mientérico na moléstia de Chagas em gatos e cães com infecção natural. Tese de doutorado. Universidade de São Paulo, Faculdade de Medicina de Ribeirão Preto, 1963.

27. Long RG, Albuquerque RH, Prata A, Barnes AJ, Adrian TE, Christofides ND, Bloom SR. Response of plasma pancreatic and gastrointestinal hormones to oral and intravenous glucose and insulin hypoglycemia in Chagas' disease Gut 21: 772-777, 1980.

28. Macedo VO. Forma indeterminada da doença de Chagas. In: Dias JCP, Coura JR, (eds), Clinica e Terapêutica da doença de Chagas, Editora FIOCRUZ, Rio de janeiro, p.135-151, 1997.

29. Machado WM. Small intestine flora in chagasic patients with megaesophagus and/or megacolon: study using the $\mathrm{H}_{2}$ breath test. Arquivos de Gastroenterologia de São Paulo 32: 19-23, 1995. 
30. Machado WM, Moraes-Filho JPP, Santos MAA, Bettarello A. Jejunal flora of patients with megaoesophagus secondary to Chagas' disease. Transactions of the Royal Society of Tropical Medicine and Hygiene 83: 199-201, 1989.

31. Mann SD, Debinski HS, Kamm MA. Clinical characteristics of chronic idiopathic intestinal pseudo-obstruction in adults. Gut 41: 675-681, 1997.

32. Meneghelli UG. Estudos sobre a absorção intestinal de glicose, xilose e ácido oléico 131I na forma crônica da moléstia de Chagas. Tese de doutorado. Universidade de São Paulo, Faculdade de Medicina de Ribeirão Preto, Ribeirão Preto, 1969.

33. Meneghelli UG. Chagas' disease: a model of denervation in the study of digestive tract motility. Brazilian Journal of Medical and Biological Research 18: 255-264, 1985.

34. Meneghelli UG, Aprile LRO. Distúrbios motores do intestino delgado. In: Castro LP, Vaz Coelho LG (eds) Gastroenterologia, Medsi, Rio de Janeiro, p. 1049-1068, 2004.

35. Meneghelli UG, Aprile LRO, Oliveira RB, Martinelli ALC, Troncon LEA, Dantas RO. Feeding does not disrupt the interdigestive motor pattern in chagasic megaduodenum and megajejunum. In: Acta Gastroenterologica Latinoamericana: Resumos do XXIII Congresso Panamericano de Enfermedades Digestivas, Buenos Aires, Argentina, p47, 1993.

36. Meneghelli UG, Godoy RA, Padovan W. Hiperreatividade do intestino delgado à acetilcolina na forma crônica da moléstia de Chagas. In: Resumos do XX Congresso Brasileiro de Gastroenterologia, São Paulo, p. 20, 1968.

37. Meneghelli UG, Iazigi N, Vieira CB, Padovan W, Godoy RA. 0 teste do ácido oléico 131I na forma crônica da moléstia de Chagas. Revista Goiana de Medicina 18: 75-90, 1972.

38. Meneghellli UG, Padovan W, Lima Filho, EC, Godoy RA. Intestinal absorption of glucose in chronic Chagas' disease studied by the continuous perfusion technique. Arquivos de Gastroenterologia de São Paulo 8: 109-118, 1971.

39. Meneghelli UG, Reis LCF. Estudos sobre o metabolismo dos hidratos de carbono na moléstia de Chagas. III. A prova de sobrecarga oral de galactose. Revista da Associação Médica Brasilileira 13: 3-10, 1967.

40. Meneghelli UG, Reis LCF, Vichi FL, Lima Filho EC. Estudos sobre 0 metabolismo de hidratos de carbonio na moléstia de Chagas. IV. Provas intravenosas de tolerância à glicose e à tolbutamida. Revista Paulista de Medicina 75: 281- 288, 1969

41. Meneghelli UG, Vieira CB, Padovan W, Godoy RA. 0 teste da d-xilose na moléstia de Chagas. Arquivos de Gastroenterologia de São Paulo 8: 191198, 1971.

42. Menezes $\mathrm{H}$, Oliveira JSM. A motilidade intestinal (duodeno) de ratos chagásicos crônicos. Revista Brasileira de Medicina 23: 779-782, 1966.

43. Mott CB, Guarita DR, Sipahi AM, Bettarello A. Hormônios gastroenteropancreáticos em portadores da doença de Chagas crônica. Revista do Hospital das Clínicas da Faculdade de Medicina de São Paulo 44: 63-72, 1989

44. Okumura M, Correa Neto A. Produção experimental de "megas" em animais inoculados com Trypanosoma cruzi. Revista do Hospital das Clínicas da Faculdade de Medicina de São Paulo 16: 338-341, 1961.

45. Oliveira RB, Castillo T, Wingate DL, Meneghelli UGl. Chagas disease as a model for the identification of small bowel motor abnormalities in enteric neuropathy. Gastroenterology 108: A592, 1995.

46. Oliveira RB, Meneghelli UG, Godoy RA, Dantas RO, Padovan W. Abnormalities of interdigestive motility of the small intestine in patients with Chagas' disease. Digestive Diseases and Sciences 28: 294-299, 1983.

47. Oliveira RB, Meneghelli UG, Padovan W, Dantas RO, Godoy RA. A absorção intestinal do ácido olêico 131I administrado por via intrajejunal em chagásicos crônicos. Revista Goiana de Medicina 24: 1-16, 1978.

48. Oliveira RB, Troncon LEA, Meneghelli UG, Padovan W, Dantas RO, Godoy RA. Impaired gastric accommodation to distension and rapid gastric emptying in patients with Chagas' disease. Digestive Diseases and Sciences 25: 790-794, 1980.

49. Petri K, Eisen H. Chagas' disease: a model for the study of autoimmune diseases. Parasitology Today 5: 111-116, 1989
50. Primavera KSC, Umezawa ES, Peres BA, Camargo ME, Hoshino-Shimizu S. Chagas' disease: IgA, IgM and IgG antibodies to T. cruzi amastigote, trypomastigote and epimastigote antigens in acute and different chronic forms of the disease. Revista do Instituto de Medicina Tropical de São Paulo 32: 172-180, 1990.

51. Quintanilha AGG, Santos MAA, Avila-Campos MJ, Saad WA, Pinotti HW, Zilberstein B. Chagasic megacolon and proximal jejunum microflora. Scandinavian Journal of Gastroenterology 35: 632-636, 2000.

52. Raia AA, Acquarone P, Correa Neto A. Contribuição ao estudo da etiopatogenia do megaduodenum. Revista Goiana de Medicina 7: 1-61, 1961.

53. Raia AA, Gama-Rodrigues JJ. Megaduodenum. In: Raia AA (ed) Manifestaç̃oes digestivas da moléstia de Chagas, Sarvier, São Paulo, pp 191-202, 1983

54. Rassi A, Rezende JM, Doles J. Caso de doença de Chagas observado desde 0 período inicial da infeccãa, com aparecimento precoce de megaesofago e megacolo. Revista da Sociedade Brasileira de Medicina Tropical 2: 303 315, 1968.

55. Reis LCF, Oliveira HL, Vieira CB. Curvas glicêmicas anormais observadas em pacientes com a forma crônica da moléstia de Chagas. Revista Goiana de Medicina 6: 155-165, 1960.

56. Rezende JM. Forma digestiva da moléstia de Chagas. Revista Goiana de Medicina 5: 193-227, 1959.

57. Rezende JM. Manifestações digestivas da doença de Chagas. In: Dani R, Castro LP (eds) Gastroenterologia Clínica, 3ạ edição, Guanabara-Koogan SA, Rio de Janeiro, p.1729-1755, 1993.

58. Ribeiro ALP, Rocha MOC. Forma indeterminada da doença de Chagas: consideracões acerca do diagnóstico e do prognóstico. Revista da Sociedade Brasileira de Medicina Tropical 31: 301-314, 1998.

59. Santos MR, Sobrado Jr CW, Damião AOMC, Rodrigues JG, Irya KK, Pinotti HW, Bettarello A, Moraes Filho JPP. Megaíleo chagásico. Descrição de um caso. Revista do Instituto de Medicina Tropical de São Paulo 30: 293-295, 1988

60. Tafuri WL. Patogenia dos megas. In: Castro LP, Rocha PRS, Cunha AS (eds) Tópicos em Gastroenterologia 2. Medsi, Rio de Janeiro, p. 163-173, 1991.

61. Tafuri WL, Maria TA, Lopes ER. Lesões do plexo mientérico do esôfago, do jejuno e do colo de chagásicos crônicos. Estudo ao microscópio eletrônico. Revista do Instituto de Medicina Tropical de São Paulo 13: 76-91, 1971.

62. Tarleton RL. Chagas disease: a role for autoimmunity? Trends in Parasitology 19: 447-451, 2003.

63. Tarleton RL, Sun J, Zhang L, Ponstan Ml. Depletion of T-cell populations results in exacerbation of myocarditis and parasitism in experimental Chagas' disease. Infection and Immunology 62: 1820-1829, 1994.

64. Tarleton RL, Zhang L. Chagas disease etiology: autoimmunity or parasite persistence? Parasitology Today 15: 94-99, 1999.

65. Toledo PA, Fonseca LC. Radiologia do intestino delgado na acalásia. 0 Hospital 44: 317-329, 1953.

66. Toskes PP. Bacterial overgrowth of the gastrointestinal tract. Advances in Internal Medicine 38: 387-407, 1993.

67. Troncon LEA. Doença de Chagas: enteropatia. In: Castro LP, Rocha PRS, Cunha AS (eds) Tópicos em Gastroenterologia 2. Medsi, Rio de Janeiro, pp. 229-244, 1991.

68. Troncon LEA, Aprile LR, Oliveira RB, Iazigi N. Abnormally rapid gastric emptying of an isosmotic liquid meal in patients with megaduodenum. Digestive Diseases and Sciences 45: 2145-2150, 2000.

69. Troncon LEA, Oliveira RB, Romanello LMF, Rosa-e-Silva L, Pinto MC, Iazigi N. Abnormal progression of a liquid meal through the stomach and small intestine in patients with Chagas' disease. Digestive Diseases and Sciences 38: 1511-1517, 1993.

70. Vieira CB, Godoy RA, Meneghelli UG. Gastropatia chagásica crônica: novas perspectivas de diagnóstico. Revista da Associação Médica Brasileira 15: 383-384, 1969

71. Zhang L, Tarleton RL. Parasite persistence correlates with disease severity and localization in chronic Chagas' disease. Journal Infectious Diseases 180: 480-486, 1999. 